Gray, G. M. \& Macfarlane, M. G. (1961). Biochem. J. 81, 480.

Hanes, C. S. \& Isherwood, F. A. (1949). Nature, Lond., 164, 1107.

Hirsch, J. \& Ahrens, E. H. (1958). J. biol. Chem. 233, 311. Igarashi, H., Zama, K. \& Katada, M. (1958). Nature, Lond., $181,1282$.
Kittredge, J. S., Roberts, E. \& Simonsen, D. G. (1962). Biochemistry, 1, 624.

Lea, C. H. \& Rhodes, D. N. (1953). Biochem. J. 54, 467.

Marinetti, G. V. (1962). J. Lipid Res. 3, 1.

Rapport, M. M. \& Alonzo, N. (1955). J. biol. Chem. 217, 193.

Siegel, S. M. (1960). Experientia, 16, 358.

Biochem. J. (1964) 90, 122

\title{
Effects of Iron Deficiency and of Zinc Deficiency on the Activities of some Enzymes in Mycobacterium smegmatis
}

\author{
BY F. G. WINDER \\ Department of Biochemistry, Trinity College, Dublin \\ AND C. O'HARA* \\ Laboratories of the Medical Research Council of Ireland, Trinity College, Dublin
}

(Received 28 May 1963)

When the growth medium of Mycobacterium smegmatis is depleted of iron or zinc, limitation of growth of the culture is finally brought about by exhaustion of the supply of the depleted metal. When this occurs certain characteristic changes occur in the composition of the bacteria that give some indications of the synthetic pathways which are affected earliest by deficiences of these metals (Winder \& O'Hara, 1962; Ratledge \& Winder, 1962). Further information on the effects of these deficiences has been sought by following the activities of some enzymes in these depleted cultures and these results are reported in the present paper. A preliminary report on some of this work has been published (Winder, O'Hara \& Ratledge, 1961).

\section{EXPERIMENTAL}

Organism. Mycobacterium smegmatis is a strain of unknown origin used for previous studies (Winder \& O'Hara, 1962).

Arowth and harvesting. The preparation of metal-depleted medium, treatment of glassware and growth of the bacteria were described by Winder \& O'Hara (1962) and Ratledge \& Winder (1962). Metals were added to the depleted medium to give the following concentrations (per ml.): in normal medium, 2.16 $\mu \mathrm{g}$. of $\mathrm{Fe}^{3+}$ and $0 \cdot 42 \mu \mathrm{g}$. of $\mathrm{Zn}^{2+}$ ions; in irondeficient medium, $0 \cdot 27 \mu \mathrm{g}$. of $\mathrm{Fe}^{3+}$ and $0 \cdot 42 \mu \mathrm{g}$. of $\mathrm{Zn}^{2+}$ ions; in zinc-deficient medium, $2 \cdot 16 \mu \mathrm{g}$. of $\mathrm{Fe}^{3+}$ and $0.035 \mu \mathrm{g}$. of $\mathrm{Zn}^{2+}$ ions. Surface cultures only were used. After 2,3 and 4 days one or more flasks of each type of culture were taken, the cells were collected in a Buchner funnel on

* Present address: The Agricultural Institute, Oak Park, Carlow, Ireland.
Whatman no. 1 paper and washed with water under gentle suction.

Preparation of extracts. The cells were transferred to Mickle disintegrator tubes (about 50-100 mg. of cell protein/tube) and about $5 \mathrm{ml}$. of the buffer appropriate to the enzyme determination (usually $0.05 \mathrm{M}$-potassium phosphate, pH 7.5) was added together with a volume of Ballotini beads about equal to the volume of the cells. The tubes were placed in a refrigerator at $-10^{\circ}$ until just frozen and were then shaken in a Mickle disintegrator at maximum amplitude for three $10 \mathrm{~min}$. periods, refreezing at $-10^{\circ}$ between periods. The extracts were centrifuged at $2000 \mathrm{~g}$ for $15 \mathrm{~min}$. at $4^{\circ}$ and the supernatant was removed for assay of enzyme activity and for protein determination by the biuret method (Layne, 1957). Preliminary studies were carried out to determine for each enzyme the optimum disintegration time. The above procedure led to extraction of all the enzymes studied except aconitate hydratase, which was inactivated to an undesirable extent. Aconitate hydratase was extracted by grinding the cells with an equal volume of Ballotini beads in a chilled mortar for about 5 min. with gradual addition of chilled buffer. The extracts were centrifuged as before and the supernatants were used as enzyme. This method gave minimal inactivation of the enzyme.

The enzymes were assayed also in the residues after centrifuging but in all the enzymes the activity was much greater in the supernatant and it is this latter value which is given throughout this paper. All enzyme assays except that of the aminotransferase were done at $18-20^{\circ}$.

\section{Assay procedures}

Glycerol dehydrogenase (glycerol-NAD oxidoreductase, $E C$ 1.1.1.6). This enzyme was determined according to the method of Burton (1955). The reaction mixture contained, in a final volume $3.0 \mathrm{ml}$.: $500 \mu$ moles of glycerol, $0.5 \mu$ mole of NAD, $100 \mu$ moles of sodium pyrophosphate buffer 
(pH 9.0) and usually $0.2 \mathrm{ml}$. of extract (i.e. about $2 \mathrm{mg}$. of protein). $\Delta E_{\mathbf{3 4 0}}$ was determined during the initial $4 \mathrm{~min}$. The control cell contained the above-mentioned constituents except glycerol. The number of units of enzyme present $(\mu \mathrm{m}-\mathrm{moles}$ of $\mathrm{NADH}$ formed $/ \mathrm{min}$.) was calculated from $\Delta \epsilon 6 \cdot 3 \times 10^{3}$.

Lactate dehydrogenase. The method of Appleby \& Morton (1959) was used. The reaction mixture contained, in a final volume $3.0 \mathrm{ml}$ : : 1.34 $\mu$ moles of sodium lactate, $3 \mu$ moles of $\mathrm{K}_{3} \mathrm{Fe}(\mathrm{CN})_{6}$, $275 \mu$ moles of sodium pyrophosphate buffer (pH $9 \cdot 0$ ) and usually $0.2 \mathrm{ml}$. of extract. $\Delta \boldsymbol{E}_{\mathbf{4 2 0}}$ was determined during the initial $4 \mathrm{~min}$. The control cell lacked ferricyanide. A blank determination was done subsequently in which lactate was omitted from the reaction mixture. The number of units of enzyme present [half the number of $\mu \mathrm{m}$-moles of $\mathrm{K}_{3} \mathrm{Fe}(\mathrm{CN})_{6}$ reduced/min.] was calculated from $\Delta \epsilon 0.88 \times 10^{3}$ and by making allowance for the blank rate.

Succinate dehydrogenase [succinate-(acceptor) oxidoreductase, $E C$ 1.3.99.1]. The method of Bonner (1955) was used. The reaction mixture contained, in a final volume $3.0 \mathrm{ml}$.:

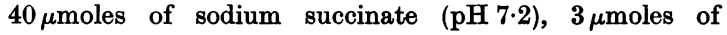
$\mathrm{K}_{3} \mathrm{Fe}(\mathrm{CN})_{6}, 30 \mu$ moles of $\mathrm{KCN}(\mathrm{pH} \mathrm{7.2}), 320 \mu$ moles of potassium phosphate buffer $(\mathrm{pH} 7 \cdot 2)$ and usually $0.20 \mathrm{ml}$. of extract. $\Delta E_{400}$ was determined during the initial $4 \mathrm{~min}$. The control cell lacked ferricyanide. A blank determination was also made, in which succinate was omitted from the reaction mixture. The number of units of enzyme present [half the number of $\mu \mathrm{m}$-moles of $\mathrm{K}_{3} \mathrm{Fe}(\mathrm{CN})_{6}$ reduced/min.] was calculated from $\Delta \epsilon 0.88 \times 10^{3}$ and by making allowance for the blank rate.

Aconitate hydratase (citrate hydro-lyase, EC 4.2.1.3). The method of Anfinsen (1955) was used. The reaction mixture contained: $2.9 \mathrm{ml}$. of $0.03 \mathrm{M}$-citrate in $0.05 \mathrm{M}$-potassium phosphate buffer, $\mathrm{pH} 7 \cdot 4$, and $0.1 \mathrm{ml}$. of extract. $\Delta E_{240}$ was determined during the initial $4 \mathrm{~min}$. Citrate was omitted from the control cell. The number of units of enzyme present ( $\mu \mathrm{m}$-moles of cis-aconitate formed $/ \mathrm{min}$.) was calculated from $\Delta \epsilon 4.38 \times 10^{3}$.

$\mathrm{NADH}$-cytochrome c reductase $\left(\mathrm{NADH}_{2}\right.$-cytochrome c oxidoreductase, $E C$ 1.6.2.1). The method of Mahler (1955) was used. The reaction mixture contained, in a final volume $3 \mathrm{ml}$.: $0.6 \mu$ mole of NADH, $1.0 \mathrm{mg}$. of ferricytochrome $c$, $3 \mu$ moles of $\mathrm{KCN}, 200 \mu$ moles of potassium phosphate buffer (pH 7.5) and $0.2 \mathrm{ml}$. of extract. $\Delta E_{550}$ was followed for the first minute. Enzyme was omitted from the blank cell. The number of units of enzyme present ( $\mu \mathrm{m}$-moles of cytochrome $c$ reduced/min.) was calculated from $\Delta \epsilon$ $27 \cdot 7 \times 10^{3}$.

Rate of oxidation of $N A D H$. The reaction mixture contained, in a final volume $3 \mathrm{ml} .: 0 \cdot 2 \mu$ mole of NADH, $200 \mu$ moles of potassium phosphate buffer ( $\mathrm{pH} \mathrm{7.4)}$ and $0.1 \mathrm{ml}$. of extract. $\Delta E_{340}$ was followed for the first $4 \mathrm{~min}$. The number of units of enzyme present ( $\mu \mathrm{m}$-moles of NADH oxidized $/ \mathrm{min}$.) was calculated from $\Delta \epsilon 6.3 \times 10^{3}$.

Catalase (hydrogen peroxide-hydrogen peroxide oxidoreductase, $E C$ 1.11.1.6). The reaction mixture contained, in a final volume $3 \mathrm{ml}$.: $20 \mu$ moles of potassium phosphate buffer ( $\mathrm{pH} 7 \cdot 0$ ), $1 \mathrm{ml}$. of extract suitably diluted and $100 \mu$ moles of $\mathrm{H}_{2} \mathrm{O}_{2}$. The reaction was stopped $2 \mathrm{~min}$. after addition of the peroxide by rapidly running in $1.0 \mathrm{ml}$. of titanium sulphate reagent (conc. $\mathrm{H}_{2} \mathrm{SO}_{4}$ saturated near its boiling point with $\mathrm{TiO}_{2}$, cooled, diluted with an equal volume of water, cooled and the supernatant used), mixing and centrifuging. The extinction of the supernatant was read at $400 \mathrm{~m} \mu$. A zero-time determination and a blank determination (without peroxide) were also made. The specific catalase activity of the preparation was calculated from the formula for a first-order reaction

$$
\frac{2 \cdot 3}{t \times c} \log \frac{E_{0}-E_{b}}{E_{t}-E_{b}} \text { l./g. of protein } / \mathrm{min} \text {. }
$$

where $t$ is the $2 \mathrm{~min}$. reaction time, $c$ is the concentration of protein/l. of reaction mixture, and $E_{0}, E_{t}$ and $E_{b}$ are the readings at zero time, after $2 \mathrm{~min}$. and without peroxide respectively.

Peroxidative activity towards pyrogallol. A portion (1 ml.) of $0.1 \mathrm{M}$-potassium phosphate buffer, $\mathrm{pH} 7 \cdot 4$, and $1 \mathrm{ml}$. of extract were placed in each of two $1 \mathrm{~cm}$. cuvettes; $1.0 \mathrm{ml}$. of $1 \%(w / v)$ pyrogallol was added to the blank cuvette and the same addition was made $10 \mathrm{sec}$. later to the analytical cuvette, both cuvettes being stirred immediately after the addition. The spectrophotometer was rapidly balanced at $430 \mathrm{~m} \mu$ with the blank cuvette in position and a reading taken 10 sec. later with the analytical curette in position. A portion $\left(40 \mu \mathrm{l}\right.$.) of $1 \%(\mathrm{w} / \mathrm{v}) \mathrm{H}_{2} \mathrm{O}_{2}$ was added to the analytical cuvette, a stop-clock started, and the contents of the curvette were stirred rapidly. After $4 \mathrm{~min}$. 50 sec. the spectrophotometer was balanced with the blank cuvette in position and the reading on the analytical cuvette taken 10 sec. later. The slit width was kept as near to constant as possible. The number of $\mu$ moles of purpurogallin formed was calculated from a standard curve obtained from solutions of purpurogallin in $33 \mathrm{~mm}$-potassium phosphate buffer, pH 7·4.

Alanine aminotransferase (L-alanine-2-oxoglutarate aminotransferase, $E C$ 2.6.1.2). This enzyme was assayed at $37^{\circ}$ on $0.2 \mathrm{ml}$. of extract according to the method of Reitman \& Frankel (1957) as described in Sigma Technical Bulletin no. 505 and by using Sigma Kit no. 505-P (Sigma Chemical Co., St Louis, Mo., U.S.A.). Activity was calculated in terms of $\mu \mathrm{m}$-moles of pyruvic acid formed $/ \mathrm{min}$.

Materials. $\mathrm{NAD}^{+}(98-100 \%), \quad \mathrm{NADH} \quad(98-100 \%)$, cytochrome $c$ (horse-heart, type II) and purpurogallin were obtained from Sigma Chemical Co., St Louis, Mo., U.S.A. Calcium L (+)-lactate (grade B) was obtained from California Corp. for Biochemical Research, Los Angeles, Calif., U.S.A. Other chemicals were of analytical reagent grade except for pyrogallol, which was B.P. grade.

Instruments. A Beckman DU 2 spectrophotometer was used for all photometric work and Radiometer 21 and 22 $\mathrm{pH}$-meters (Radiometer, Copenhagen) were used for $\mathrm{pH}$ determinations.

Statistical treatment of results. Each mean value given was based on several separate experiments (the number is given with each figure), not on replication within an experiment. The significance of differences between means was determined by the $t$ test.

\section{RESULTS AND DISCUSSION}

The growth curves in these experiments were close to those reported by Winder \& O'Hara (1962). Cultures in all three types of medium grew at about the same rate for the first $48 \mathrm{hr}$. Shortly after this the growth rate in both metal-deficient cultures 
dropped below that in the normal cultures and after $72 \mathrm{hr}$. their growth had practically ceased. In the normal cultures the corresponding fall in growth rate (in this case due to exhaustion of the carbon and nitrogen sources) took place about $12 \mathrm{hr}$. later than in the deficient cultures. The results for the normal cultures (Table 1) showed that exhaustion of the carbon and nitrogen sources had comparatively little effect on the activity of any of the enzymes studied. Some significant changes were observed, but in no case did the mean value at the time of highest activity differ from that at the time of lowest activity by a factor as high as two.

The enzyme activities fell into three groups in their response to iron deficiency : those elevated or not significantly affected (lactate dehydrogenase, alanine aminotransferase and $\mathrm{NADH}$-oxidizing activity); those unaffected on the second day but significantly below normal thereafter (glycerol dehydrogenase, catalase and peroxidative activity towards pyrogallol); and those below normal even on the second day (succinate dehydrogenase, aconitate hydratase and $\mathrm{NADH}$-cytochrome $c$ reductase). Those in the first group may reasonably be assumed to have no requirement for iron for their synthesis or action. This tends to confirm that there is no lactate dehydrogenase of the cytochrome $b_{2}$ type (EC 1.1.2.3) in this organism. Two of the activities in the second group depend on haem compounds. The occurrence of glycerol dehydrogenase in this group suggests that it also might require iron for its synthesis or activity in this organism, but this has not been shown for this enzyme from other organisms (Burton, 1955; Edson, 1961). It is possible that the effect of iron deficiency is indirect, such as through repression brought about by the accumulation of an intermediate: this enzyme is inducible in some bacteria (Lin \& Magasanik, 1960; Jacobs \& VanDemark, 1960).

Each of the enzymes in the third group, which respond very rapidly to iron deficiency, has been shown, in some organisms, to contain non-haem iron (Slater, 1961; Dickman, 1961; Massey, 1961; Neilands, 1961), though this does not appear to be the case with the NADH-cytochrome $c$ reductase of bacteria (Brodie, 1955; Neilands, 1961).

Aconitate hydratase, alanine aminotransferase and NADH-oxidizing activity were not decreased by zinc deficiency during the period of the experiments. Succinate-dehydrogenase, catalase and peroxidative activity towards pyrogallol showed a small fall in activity on the fourth day whereas NADH-cytochrome $c$ reductase showed it somewhat earlier. This late fall may be due to slight proteolysis, which seems to occur at a fairly late stage of zinc deficiency (Winder \& O'Hara, 1962).
The earlier and larger fall in glycerol-dehydrogenase activity suggests a special requirement for zinc for the synthesis or function of this enzyme. This is the case with a number of other $\mathrm{NAD}^{+}$. dependent dehydrogenases (Vallee, 1960), although it has not been demonstrated for glycerol dehydrogenase (Burton, 1955; Edson, 1961) and in fact the form extracted from Aerobacter aerogenes is inhibited by zinc (Lin \& Magasanik, 1960). Again the effect may be due to repression. Lactatedehydrogenase activity fell still earlier but we, like most other workers (Edson \& Cousins, 1953; Cousins, 1956), have found no evidence for the presence of a $\mathrm{NAD}^{+}$-dependent lactate dehydrogenase (EC 1.1.1.27), which might account for the effect of zinc (Vallee, 1960). The activity assayed was probably due entirely to the decarboxylating lactate oxidase of mycobacteria (EC 1.1.3.2) (Yamamura, Kusunose \& Kusunose, 1952; Cousins, 1956; Sutton, 1954, 1955, 1957). These workers failed to show the presence of any metal in this enzyme but it is possible that zinc is involved in a cofactor coupling the lactate oxidase with ferricyanide. Such a cofactor is necessary to couple the purified oxidase with acceptors having a redox potential less than $+0 \cdot 19 \mathrm{v}$ at $\mathrm{pH} \mathrm{7.0}$ (Sutton, 1955), though the redox potential of ferricyanide is higher than this.

The activity of NADH-cytochrome $c$ reductase could account for part only of the high rate of NADH oxidation, and there was no correlation between the responses of these two activities to different cultural conditions. There are several possible explanations for this, including the possibility that some of the NADH disappearance took place by a mechanism other than oxidation. A deficiency of either iron or zinc stimulated the cytochrome $c$-independent route of $\mathrm{NADH}$ disappearance.

Peroxidative activity towards pyrogallol correlated closely with catalase activity: the regression coefficient of peroxidase activity on catalase activity was highly significant $(P<0.001)$ when tested by the methods of variance analysis. Further, variance analysis (with the $F$ test and the $t$ test) on the ratios of the catalase activity to the peroxidative activity for each extract showed that there was no significant difference between the response of catalase activity and that of peroxidative activity to the progressive deficiencies of iron, zinc, or carbon and nitrogen induced during these experiments. These results are in keeping with the suggestion, which has been made on other grounds, that both activities in mycobacteria are functions of one enzyme (Winder, 1960). Studies on isoniazid-resistant strains of mycobacteria have shown that the peroxidative activity is not due to the other major haem enzymes (Winder, 1963). 


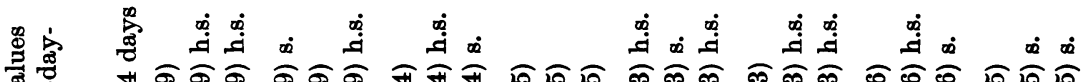

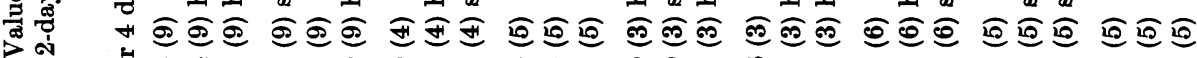

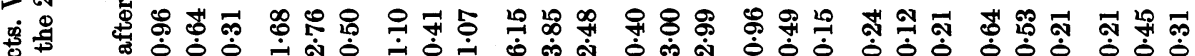

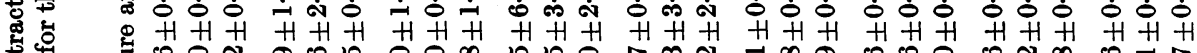
弯

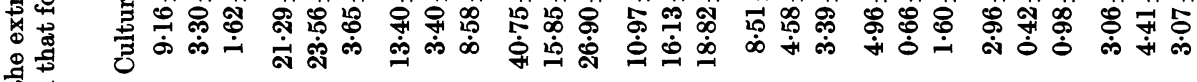

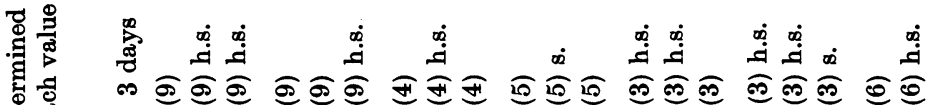

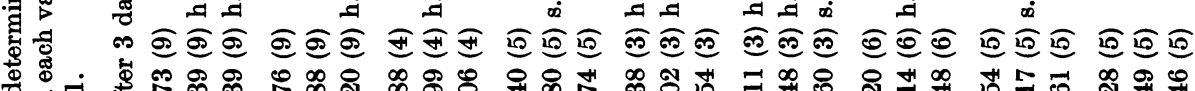

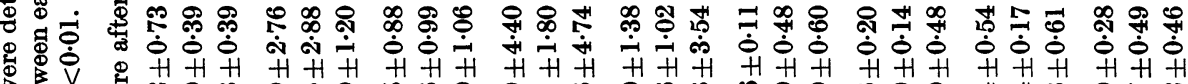

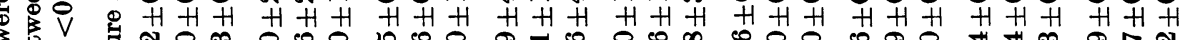

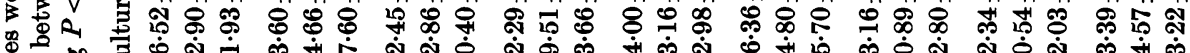

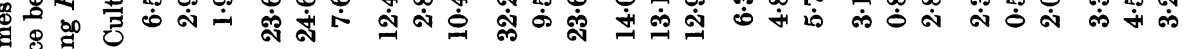
S.

so: 9

है

है

8

胥

है

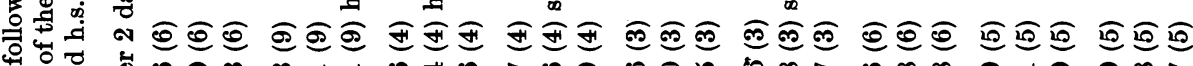

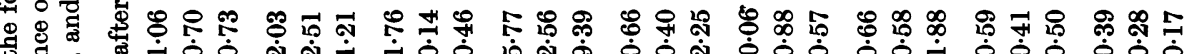

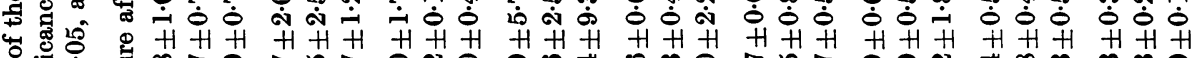

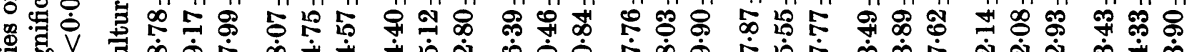

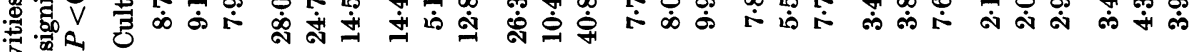

है

흉 옥

官客。 पै 열

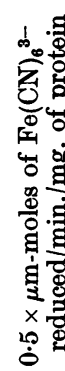

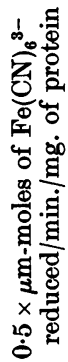

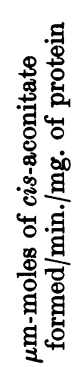

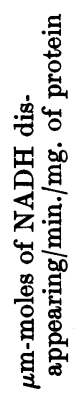

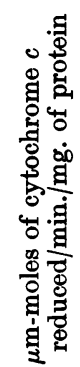

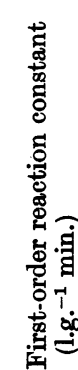

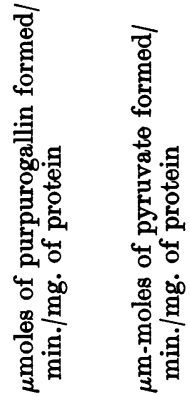




\section{SUMMARY}

1. Mycobacterium smegmatis was grown on the surface of normal, iron-deficient and zinc-deficient media. The concentrations in the deficient media permitted a normal growth rate for 2 days. A number of enzymes were determined in cell-free extracts prepared from these cultures at the end of 2,3 and 4 days' growth.

2. In the iron-deficient medium, lactate-dehydrogenase, alanine-aminotransferase and NADHoxidizing activity were elevated or were not significantly affected; glycerol-dehydrogenase, catalase and peroxidative activity towards pyrogallol were unaffected on the second day but were significantly below normal thereafter; succinate dehydrogenase, aconitate hydratase and NADHcytochrome $c$ reductase were below normal throughout.

3. In the zinc-deficient medium, aconitatehydratase, alanine-aminotransferase and NADHoxidizing activity were normal or elevated; succinate dehydrogenase, NADH-cytochrome $c$ reductase, catalase and peroxidative activity towards pyrogallol fell slightly about the fourth day, probably owing to autolysis; an earlier and larger fall occurred in glycerol-dehydrogenase and lactate-dehydrogenase activity.

4. NADH-cytochrome $c$ reductase can account for only part of the NADH-oxidizing activity of the extracts; the two activities varied independently.

5. Peroxidative activity towards pyrogallol followed catalase activity closely, in keeping with the concept that both activities are functions of one enzyme.

We thank Miss Louise Hackett for technical assistance, Mr M. J. Carroll, Biochemistry Department, Trinity College, for advice on statistics, and Dr V.C. Barry, Director of Laboratories of the Medical Research Council of Ireland, for his interest in this work, which was supported in part by a research grant (E-2842) from the Institute of Allergy and Infectious Diseases, United States Public Health Service, and by Arthur Guinness, Son and Co. (Dublin) Ltd.

\section{REFERENCES}

Anfinsen, C. (1955). In Methods in Enzymology, vol. 1, p. 695. Ed. by Colowick, S. P. \& Kaplan, N. O. New York: Academic Press Inc.
Appleby, C. A. \& Morton, R. K. (1959). Biochem. J. 71, 492.

Bonner, W. D. (1955). In Methods in Enzymology, vol. 1, p. 725. Ed. by Colowick, S. P. \& Kaplan, N. O. New York: Academic Press Inc.

Brodie, A. F. (1955). In Methods in Enzymology, vol. 2, p. 693. Ed. by Colowick, S. P. \& Kaplan, N. O. New York: Academic Press Inc.

Burton, R. M. (1955). In Methods in Enzymology, vol. 1, p. 397. Ed. by Colowick, S. P. \& Kaplan, N. O. New York: Academic Press Inc.

Cousins, F. B. (1956). Biochem. J. 64, 297.

Dickman, S. R. (1961). In The Enzymes, vol. 5, p. 495. Ed. by Boyer, P. D., Lardy, H. \& Myrbäck, K. New York: Academic Press Inc.

Edson, N. L. (1961). In Biochemists' Handbook, p. 326. Ed. by Long, C. London: E. and F. N. Spon Ltd.

Edson, N. L. \& Cousins, F. B. (1953). Nature, Lond., 171, 702.

Jacobs, N. J. \& VanDemark, A. J. (1960). J. Bact. 79, 532.

Layne, E. (1957). In Methods in Enzymology, vol. 3, p. 447. Ed. by Colowick, S. P. \& Kaplan, N. O. New York: Academic Press Inc.

Lin, E. C. \& Magasanik, B. (1960). J. biol. Chem. 235, 1820.

Mahler, H. (1955). In Methods in Enzymology, vol. 2, p. 688. Ed. by Colowick, S. P. \& Kaplan, N. O. New York: Academic Press Inc.

Massey, V. (1961). In Biochemists' Handbook, p. 493. Ed. by Long, C. London: E. and F. N. Spon Ltd.

Neilands, J. B. (1961). In Biochemists' Handbook, p. 355. Ed. by Long, C. London: E. and F. N. Spon Ltd.

Ratledge, C. \& Winder, F. G. (1962). Biochem. J. 82, 98.

Reitman, S. \& Frankel, S. (1957). Amer. J. clin. Path. 28, 56.

Slater, E. C. (1961). In Biochemists' Handbook, p. 369. Ed. by Long, C. London: E. and F. N. Spon Ltd.

Sutton, W. B. (1954). J. biol. Chem. 210, 309.

Sutton, W. B. (1955). J. biol. Chem. 216, 749.

Sutton, W. B. (1957). J. biol. Chem. 226, 395.

Vallee, B. L. (1960). In The Enzymes, vol. 3, p. 225. Ed. by Boyer, P. D., Lardy, H. \& Myrbäck, K. New York: Academic Press Inc.

Winder, F. (1960). Amer. Rev. resp. Dis. 81, 68.

Winder, F. (1963). In The Chemotherapy of Tuberculosis. Ed. by Barry, V. C. London: Butterworth (in the Press).

Winder, F. G. \& O'Hara, C. (1962). Biochem. J. 82, 98.

Winder, F. G., O'Hara, C. \& Ratledge, C. (1961). Biochem. J. 80, 21 P.

Yamamura, Y., Kusunose, M. \& Kusunose, E. (1952). Nature, Lond., 170, 207. 